\title{
A MARKET ENTRY CONCEPT FOR A COMMERCIAL BANK TO ENTER THE FINANCIAL MARKET IN POLAND
}

\section{MONIKA PETTERSEN-SOBCZYK}

University of Szczecin, Faculty of Management and Economics of Services, POLAND

monika.pettersen@wzieu.pl

\begin{abstract}
RECEIVED
ACCEPTED

10 December 2018

28 December 2018

JEL

CLASSIFICATION

G21

KEYWORDS

financial market, market entry, commercial bank

ABSTRACT

The purpose of this paper is to develop a market entry concept for a new banking enterprise to enter the financial market in Poland. The research methods applied to attain this purpose included: reports and source data analysis, comparative analysis and SWOT analysis, inductive and deductive reasoning methods, a survey involving commercial bank customers in Poland, and a synthesis of the obtained results. This paper presents the research results as well as the outcome of the deliberations, being a concept for a new commercial bank to enter the financial market in Poland.
\end{abstract}

\section{Introduction}

The banking services market in Poland is specific and relatively new. In fact, it was not until 1989 that it started functioning as a result of Poland's transition to a market economy. The Polish banking market players include a number of banking and para banking enterprises, both foreign and national. One could think that this market has already been saturated and closed (Kotliński, 2018, p. 162), which means it would be very hard for any new 
enterprise to make a viable market entry. However, the Polish market has been saturated only on the supply side, while there is still a growth potential in the demand (there is still a large number of adult Poles who do not have bank accounts). There is evidence (see the example of Alior Bank which obtains very good results on the financial market) indicating that adequately applied promotional tools combined with an interesting and innovative range of services can make it possible for a new bank to complete a successful market entry into the Polish market.

\section{Research Methodology}

The term "new bank" which is applied throughout this article may be construed as either of the two cases: a totally new bank starting its operations on the Polish market (e.g. Alior Bank) and an existing bank that enters the Polish market (e.g. Allianz Bank). In this article, attention is focused predominantly on the entirely new entities entering the financial market in Poland.

The research studies performed for the purposes of this paper were aimed at developing a market entry concept for a new banking enterprise to enter the Polish market. The research methods applied to attain this purpose included: reports and source data analysis, comparative analysis and SWOT analysis, inductive and deductive reasoning methods, a survey involving commercial bank customers in Poland, and a synthesis of the obtained results. The results of the research studies are presented both in the descriptive and tabulated forms.

The empirical data were obtained from a survey that was carried out from February to April 2015 and involved 622 customers of commercial banks operating in Poland, which was based on the electronic survey questionnaire (CAWI) and paper survey questionnaire (PAPI). The respondent group included 442 women $(71.06 \%)$ and 189 men (28.94\%). The vast majority (72.2\%) of the respondents were bank customers aged from 18 to 34 years. The second biggest group comprised respondents aged from 35 to 49 years, and the least numerous group was composed of respondents aged $50+$. In terms of education, the vast majority (70.58\%) of the respondents had tertiary education, whereas $13.99 \%$ of the surveyed bank customers had secondary and post-secondary education, and $13.02 \%$ of the respondents declared they had attained incomplete tertiary education. The least numerous respondent groups included the bank customers with the occupational $(1.77 \%)$ and primary $(0.64 \%)$ education. The questionnaire comprised 15 survey questions and 3 demographics questions regarding age, gender, and education.

\section{The environment of hanks at the time of market entry}

The analysis of the market entry process for new banks (for the purposes of this paper, the term "new bank" will cover any of the following banks: mBank, Alior Bank, Allianz Bank, IDEA Bank, T-Mobile Usługi Bankowe, Plus Bank and Orange Finanse) is a considerably difficult and complex task. One of the methods to tackle this analysis is listing the selected micro- and macroeconomic data which characterised the banking environment in the years when the particular banks entered the market. The data are presented in Table 1.

The following data were selected for the purposes of the analysis: number of commercial banks on the market, GDP (PLN m), productive population, Lombard rate, total unemployment rate. All the data refer to the particular market entry year. The number of commercial banks existing on the market corresponds to the number of potential competitors. The GDP value indicates the general status of the Polish economy. The number of people in the productive age group constitutes the approximate number of potential customers for the banking sector (the productive age has been defined as 18-59 years for women and 18-64 years for men). The analysis also takes into account the Lombard rate, as its affects the maximum level of loan rates in commercial banks (the fourfold of the 
Lombard rate). From the point of view of any bank which is planning to enter a new financial market, the information on the Lombard rate level is important, as the lower the Lombard rate, the more customers will be interested in the banks' lending products, whereas higher levels of the Lombard rate, though generating more interest revenues for the bank, will result in fewer customers willing to avail themselves of the bank's lending products. The last indicator is the total unemployment rate which, similarly as in the case of GDP, provides information on the general status of the Polish economy.

Table 1. Selected micro- and macroeconomic data at the time of the banks' market entries

\begin{tabular}{|c|c|c|c|c|c|c|}
\hline Bank name & $\begin{array}{c}\text { Year of market } \\
\text { entry }\end{array}$ & $\begin{array}{c}\text { Number } \\
\text { of commercial banks } \\
\text { operating on the } \\
\text { market in the year } \\
\text { of market entry }\end{array}$ & $\begin{array}{l}\text { GDP (PLN m) } \\
\text { in the year } \\
\text { of market entry }\end{array}$ & $\begin{array}{c}\text { Size of productive } \\
\text { population, aged } \\
18-59 / 64 \text { (\% of total } \\
\text { population) in the } \\
\text { year of market entry }\end{array}$ & $\begin{array}{l}\text { Lombard rate } \\
\text { as at the end } \\
\text { of the year } \\
\text { of market entry }\end{array}$ & $\begin{array}{l}\text { Total } \\
\text { unemployment } \\
\text { rate as at the } \\
\text { end of the year } \\
\text { of market entry }\end{array}$ \\
\hline Alior Bank & 2008 & 52 & $1,275,508$ & 64.5 & 6.5 & 9.5 \\
\hline mBank & 2000 & 73 & 779,554 & 60.8 & 23.0 & 15.1 \\
\hline T-Mobile Usługi Bankowe & 2014 & 41 & $1,719,097$ & 63.0 & 3.0 & 11.5 \\
\hline Plus Bank & 2013 & 41 & $1,635,746$ & 63.4 & 4.0 & 13.4 \\
\hline Allianz Bank Polska & 2008 & 52 & $1,275,508$ & 64.5 & 6.5 & 9.5 \\
\hline IDEA Bank & 2010 & 49 & $1,416,585$ & 64.4 & 5.0 & 12.4 \\
\hline Orange Finanse & 2014 & 41 & $1,729,097$ & 63.0 & 3.0 & 11.5 \\
\hline
\end{tabular}

Source: own study based on the data provided by: GUS (2018), NBP (2018).

The analysis of the micro- and macroeconomic data contained in Table 1 makes it possible to define the most and the least convenient economic situation at the time of entering the market by the bank. The most convenient time for entering the Polish financial market by banks was found to be 2000 , which was the year of the market entry by mBank, despite the very high level of interest rates, the highest unemployment level and the greatest number of potential competitors on the market across the analysed periods. The reason why the year 2000 was found to be the most opportune for a new bank to enter the Polish market was in particular the period of the considerable economic growth in many sectors. The years 2010, 2013 and 2014, in which the telecom banks (T-Mobile Usługi Bankowe, Plus Bank, Orange Finanse) and IDEA Bank entered the market, were found to be moderately opportune in terms of market entry conditions, predominantly due to the smallest number of commercial banks present on the market over the researched period, which translates into the potentially lowest market competition. Moreover, 2010, 2013 and 2014 were post-crisis years when the economic situation stabilised. Although the unemployment rate was still on a high level (above 13\%), the high percentage of productive population, high GDP and low interest rates provided favourable conditions for new banks to enter the Polish financial market. The following two banks experienced the least opportune time for market entry: Alior Bank and Allianz Bank, which entered the market in 2008.

The years 2007-2008 are considered to have been the peak years of the global financial crisis which, among other things, led to losing customers' trust by banking institutions. The unfavourable factors for a new banking enterprise entering the market included the interest rates levels which were higher than in the subsequent years.

Due to the differences in the banks' operation periods, it is very difficult to compare their effectiveness; $\mathrm{mBank}$ has been operating on the Polish market for ca. 18 years, Alior Bank - for ca. 10 years, IDEA Bank - for ca. 8 years, 
and the telecom banks have been around for 3 or 4 years. Nevertheless, an attempt was made to provide such a comparison between the banks that have been operating for some years: mBank, Alior Bank and IDEA Bank. Due to the very short operating time, the telecom banks were excluded from the comparison. Assuming that, for the purposes of this paper, the competitive advantage of the banks can be established on the basis of prestigious bank rankings, the following conclusions may be drawn:

a) after 4 years of operation, mBank (formerly MultiBank) came in third in the "Newsweek's Friendly Bank" ranking in the "Bank for Mr Smith" category (Ranking przyjazny..., 2005), after the same period of operation, Alior Bank reached the 5th place in the same ranking (Ranking przyjazny..., 2014), whereas IDEA Bank was outside the Top 20. It seems that comparing the places taken by the banks in the same ranking after the same period of operation should be the most reliable approach, however, due to the changing criteria in the rankings, it was possible to base the comparison only on the "Newsweek's Friendly Bank" ranking;

b) in the Top 50 Banks ranking of the Bank Financial Monthly held in 2014, in the assets and owner's equity category, the banks in question ranked as follows: mBank came in 4th with its assets totalling PLN 104,282.8 million, Alior Bank took the 15th place with its total assets at the level of PLN 25,544.8 million, whereas IDEA Bank was outside the published list of 24 banks (Ranking 50..., 2014, p. 23). The competitive advantage for the purposes of this paper was measured by means of the volume of assets and owner's equity, hence the very good result of mBank compared to the other banks included in this analysis. According to the research study carried out by T. Siudek, P. Snarski and B. Chodera (2013), the highest level of competitiveness was shown by Alior Bank, whereas mBank was ranked third.

The above mentioned data have shown that the time of market entry (i.e. favourable or unfavourable economic conditions) had an impact on attaining a competitive advantage by a bank. This correlation is particularly noticeable on the example of mBank.

\section{New banks on the Polish financial market in the opinion of their clients}

The particularly valuable data for the purposes of this paper come from the responses of the customers who had been using the services of the new banks - mBank, Alior Bank, T-Mobile Usługi Bankowe, Orange Finanse and Plus Bank. The most numerous group among the surveyed respondents (17.9\%) were the customers of mBank which entered the Polish market in 2000. The second biggest group was represented by the customers of Alior Bank (7.6\%) followed by T-Mobile Usługi Bankowe (1.8\%). There were no responses from the customers of Orange Finanse or Plus Bank.

The analysed responses were provided by the new banks' customers, $80 \%$ of whom had tertiary education. $67 \%$ of the respondents were female, and $33 \%$ of them were male. $59 \%$ of the new banks' customers also declared using the services of other banks. This could mean that as soon as the new banks entered the market, the customers took a cautious approach to them. When they decided to start cooperation with the new banks, they did not close their accounts held with other banks, waiting to see how the new banks' operations would be developing.

The bank service factors considered the most important by the customers included: the price of offered products and services (64.5\%), the quality of offered products and services (ca. $45 \%$ ), one-stop shopping (ca. $37 \%$ ), promptness of customer service $(33 \%)$ and availability of online services $(11 \%)$.

When choosing a banking services provider, the new banks' customers considered the following factors: the price of banking products and services $(57.40 \%)$, the number of fee-free ATMs $(42.60 \%)$, the opinion of friends and 
relatives (ca. 35\%) and online banking services (over 10\%). The factors of lesser importance included: locations of bank branches, bank service quality or a wide range of products and services. Interestingly, the factors which were decisive for choosing a new bank did not totally coincide with the factors that the customers considered the most important in the bank service. Analysing the factors involved in choosing a new bank, it is possible to draw a conclusion that the new banks attracted their customers predominantly with the price (which means not only the price of banking products and services, but also the lack of ATM fees) and with online banking services (the customers indicated characteristics of a good online banking system, such as: intuitive operation, simplicity, clarity, possibility to conduct numerous transactions via the internet).

Nearly $95 \%$ of the new banks' customers were satisfied with the service provided by their bank, which was confirmed by the loyalty to the bank declared by them. The average declared level of the new banks customers' loyalty amounted to $8.28 \%$. What is more, nearly $52 \%$ of the new banks' customers declared that they would continue to be the banks' customers, as they were satisfied with the bank service. Almost $18 \%$ of the respondents declared that they would not switch to another bank, as the banking services were comparable at all the banks, so they thought there was no reason to switch banks. However, almost $16 \%$ of the customers said they stayed with their bank only because they were reluctant to go through the formalities connected with switching to another bank. Despite the declared high loyalty level, as many as $58 \%$ of the respondents declared that they would be inclined to switch to another bank, if a new bank (significantly better than the others) came into the market. It would be enough for the respondents to decide to switch to another bank if the new bank offered lower costs. This opinion was provided by over $60 \%$ of the respondents. Also, for nearly $50 \%$ of the respondents a cost reduction would be the factor that would increase the level of loyalty to their banks.

Summing up, the price of banking products and services is the predominant factor considered by the customers when choosing a bank or switching to another.

\section{The concept of a new bank market entry}

As a result of the above considerations, an original concept of a new bank market entry was developed, accounting for the factors necessary for a new bank to complete a successful market entry into the Polish financial market. These factors include:

1. Meeting any formal requirements connected with running any banking operations in Poland.

2. Implementation of the market entry process at an opportune time for running bank operations.

3. Distinguishing from the competitors, which is connected with achieving a competitive advantage by the new bank. At the initial stage of the bank's operation, the competitive advantage may be connected to an innovative offer, new distribution channels or the capital value.

4. Running an effective advertising campaign to ensure the customers' awareness of the bank's existence. It is also extremely important to involve customers in the process of creating the new bank, so as to build up relationships with the customers and win their loyalty (for instance, see the campaign of Alior Bank called "Build a new bank with us").

5. Offering an added value to customers, an element which distinguishes the new bank from its competitors (e.g. a personal account manager for each client at Alior Bank).

6. Reaching out to those members of the society who do not use banking services (e.g. possibility to pay one's bills free of charge at Alior Bank's branches). 
7. Offering more advantageous prices than the competitors. In the case of a market which has been saturated on the supply side, winning new customers is possible only by taking them over from the competitors or reaching out to the prospective customers who do not use banking services yet (which is a difficult task).

\section{Analysis of costs and benefits of a new bank market entry}

In order to see the big picture of the issues related to entering the market by a new bank, a synthetic analysis of costs and benefits was performed, taking into account various levels of the analysis: the State, the banking and financial sector, the new bank, business entities and local government units as well as individual customers (households). The synthetic approach to the issues of costs and benefits of entering the market by a new bank makes it possible to present the complexity of the process. The results of the analysis are presented in Table 2.

Table 2. Analysis of costs and benefits of entering the market by a new bank (synthetic, model-based approach)

\begin{tabular}{|c|c|c|}
\hline Analysis level & Costs and threats & Benefits and opportunities \\
\hline The State & $\begin{array}{l}\text { - risk of excessive dispersion, } \\
\text { - risk of failure of the new undertaking, generating } \\
\text { costs for the economy (e.g. losing jobs) }\end{array}$ & $\begin{array}{l}\text { - positive impact on the national and regional } \\
\text { economy, } \\
\text { - new jobs }\end{array}$ \\
\hline Banking (banking and financial) sector & $\begin{array}{l}\text { - risk of bankruptcy } \\
\text { - increased scale of competition }\end{array}$ & $\begin{array}{l}\text { - increased scale of competition, } \\
\text { - sector growth, } \\
\text { - technological and product innovations }\end{array}$ \\
\hline New bank & $\begin{array}{l}\text { - very high costs of market entry (including those } \\
\text { connected with opening a network of branches, } \\
\text { IT systems development), } \\
\text { - demand for qualified staff (employee training also } \\
\text { generates high costs) }\end{array}$ & $\begin{array}{l}\text { - opportunity to obtain considerable benefits } \\
\text { following the financial market entry }\end{array}$ \\
\hline Business entities, local government units & $\begin{array}{l}\text { - uncertainty, } \\
\text { - risk connected with choosing a new bank }\end{array}$ & $\begin{array}{l}\text { - new possibilities in terms of deposits, } \\
\text { investments and loans, } \\
\text { - innovative product offer }\end{array}$ \\
\hline Individual customers (households) & $\begin{array}{l}\text { - uncertainty, } \\
\text { - risk connected with choosing a new bank, } \\
\text { - lack of trust to the new bank, } \\
\text { - lack of recommendations from relatives/friends }\end{array}$ & $\begin{array}{l}\text { - relatively cheap products and services of the } \\
\text { new bank, } \\
\text { - higher service quality, } \\
\text { - innovative product offer }\end{array}$ \\
\hline
\end{tabular}

Source: own work.

Economic and social phenomena are usually much more complicated than they might seem. This also regards entering a banking \& financial market which is relatively saturated (on the side of the supply, but not the demand). The short history of the market presence of Alior Bank amidst dozens of banks operating on the Polish banking and financial market deserves attention of analysts who deal with financial management, particularly in terms of success factors needed by a new entity entering a difficult market, such as the banking \& financial market in Poland. As a "late follower", Alior Bank became an interesting object for further analyses, e.g. to what extent a new entity with an innovative, intelligent strategy and tactics may become a point of reference and a model to follow by other, "old" entities. 


\section{Conclusions}

The following conclusions were formulated in the course of attaining the assumed goals:

1. The Polish banking and financial market has been saturated on the supply side (there are many banking institutions operating on it), however, it has not been saturated in terms of the potential demand (the bankusing population accounts for $77 \%$ of all the Polish society). Therefore, there is still a growth potential for new banking institutions on the Polish banking and financial market, which could start cooperation with the $23 \%$ of the Polish citizens who do not use any banking services.

2. Though at first sight the idea might seem absurd, the global banking and financial crisis is a good point in time to establish and develop new financial institutions. This kind of undertaking may be relatively easy in view of the infrastructure existing on the market in combination with the availability of experienced financial professionals ready to take on new challenges inherent in starting a new bank. This situation is undoubtedly advantageous for any hesitant customers who keep looking for an appropriate bank and adequately tailored financial services. Moreover, the increased competitiveness of the financial offer on the continuously developing market will enhance the significance of the customer-focused policy implemented by the dominating financial institutions.

3. A successful market entry of a new bank is possible, provided that the bank meets a few very important conditions, including, but not limited to: building a relationship with customers from the very beginning, choosing a business model that distinguishes the bank from its competitors, offering an added value to customers.

4. The most vital factor which is decisive for customers making decisions on opening bank accounts and purchasing new financial products is the price. Banks should pay particular attention to their price policies, particularly in the context of the market perception.

5. The new banks attract customers predominantly with the price (not only the prices of banking products and services, but also the lack of ATM fees) and their online banking systems.

6. When the new banks entered the market, the customers took a cautious approach to them. Making a decision to start cooperation with the new banks, they did not close their accounts held with other banks, waiting to see how the new banks' operations would be developing.

7. In view of the saturation of the banking services market in Poland and the intense competition, winning new customers is an extremely important task for the banks. Taking over the customers from other banking institutions is possible in a situation when the bank is able to offer the potential customers something extra, which also helps reinforce the relationships with the existing customers. This may be successfully achieved via cooperation between banks and mobile phone operators.

\section{References}

GUS (2018). Roczne wskaźniki makroekonomiczne. Retrieved from: http://stat.gov.pl/wskazniki-makroekonomiczne.

Kotliński, G. (2012). Zmiany w postrzeganiu marketingu w bankowości. In: I. Pyka, J. Cichorska (eds.), Finanse w niestabilnym otoczeniu - dylematy i wyzwania. Bankowość (pp. 162). Katowice: Wydawnictwo Naukowe Uniwersytetu Ekonomicznego w Katowicach.

NBP (2018). Cykliczne materiały analityczne NBP. Retrieved from: www.nbp.pl. 
Ranking 50 największych banków w Polsce (2014). Miesięcznik Finansowy BANK, 6 (256).

Ranking przyjazny Bank Newsweeka 2005 (2005). Retrieved from: pbs.pl/x.php/1,294/Ranking-bankow-2005.html.

Ranking przyjazny Bank Newsweeka 2014 (2014). Retrieved from: biznes.newsweek.pl/przyjazny-bank-newsweeka-2014-wynikisektor-bankowy-newsweek-pl,artykuly,348575,1.html.

Siudek, T., Snarski, P., Chodera, B. (2013). Konkurencyjność banków komercyjnych i spółdzielczych w Polsce. Roczniki Ekonomii Rolnictwa i Rozwoju Obszarów Wiejskich, 100 (2). Retrieved from: www.wne.sggw.pl/czasopisma/pdf/RNR_2013_T100_z2_ s25.pdf.

Cite this article aS: Pettersen-Sobczyk, M. (2018). A market entry concept for a commercial bank to enter the financial market in Poland. European Journal of Service Management, 4 (28/2), 319-326. DOI: 10.18276/ejsm.2018.28/2-38. 